\title{
A Palladium-catalyzed Ullmann Cross-coupling/Tandem Reductive Cyclization Route to Key Members of the Uleine Alkaloid Family
}

\author{
Fei Tang, Martin G. Banwell* and Anthony C. Willis
}

Research School of Chemistry, Institute of Advanced Studies

The Australian National University, Canberra, ACT 2601, Australia

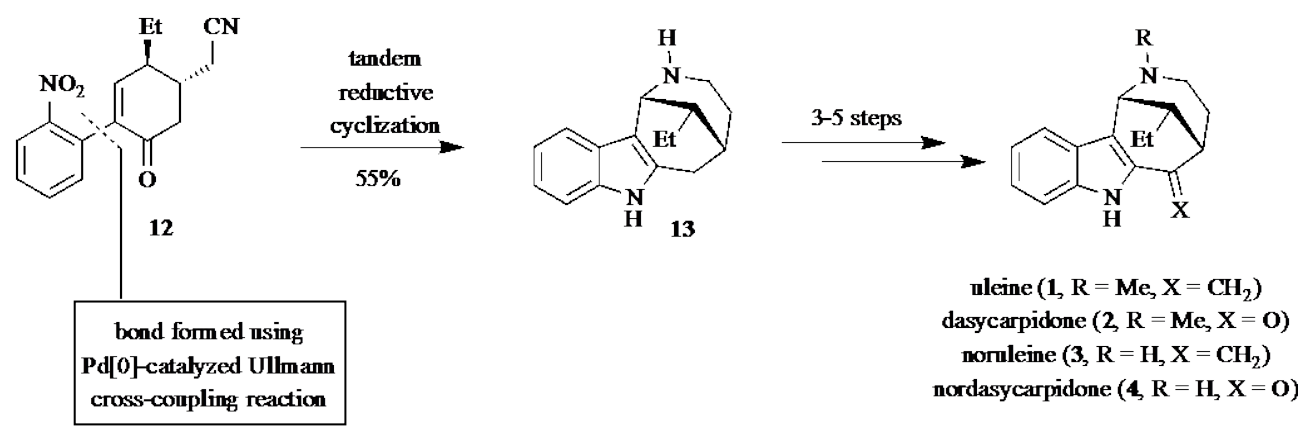

\begin{abstract}
The trisubstituted cyclohexenone 12, generated through a palladiumcatalyzed Ullmann cross-coupling reaction between $o$-iodonitrobenzene and a 4,5-transdisubstituted-2-iodo-2-cyclohexen-1-one, engaged in a tandem reductive cyclisation process upon exposure to hydrogen gas in the presence of Raney cobalt. As a result, the 1,5-methanoazocino[4,3- $b$ ]indole $\mathbf{1 3}$ was obtained and this could be readily elaborated to the racemic modifications of the alkaloids uleine, dasycarpidone, noruleine and nordasycarpidone (1-4 respectively).
\end{abstract}

\section{INTRODUCTION}


Like the more well known Strychnos alkaloids, the uleine-type natural products embody the tetracyclic 1,5 -methanoazocino[4,3-b]indole framework. ${ }^{1}$ Uleine $\quad(\mathbf{1}),{ }^{2,3}$ dasycarpidone (2), ${ }^{3}$ noruleine (3) ${ }^{3}$ and nordasycarpidone (4) ${ }^{3}$ (Figure 1), all of which have been isolated from a range of plants sources including the bark of the South American shrub Aspidosperma dasycarpon A. DC., are the 'original' and representative members of the family but others have since been identified including, for example, C20epimers ${ }^{4}$ and more highly oxygenated variants. ${ }^{5}$
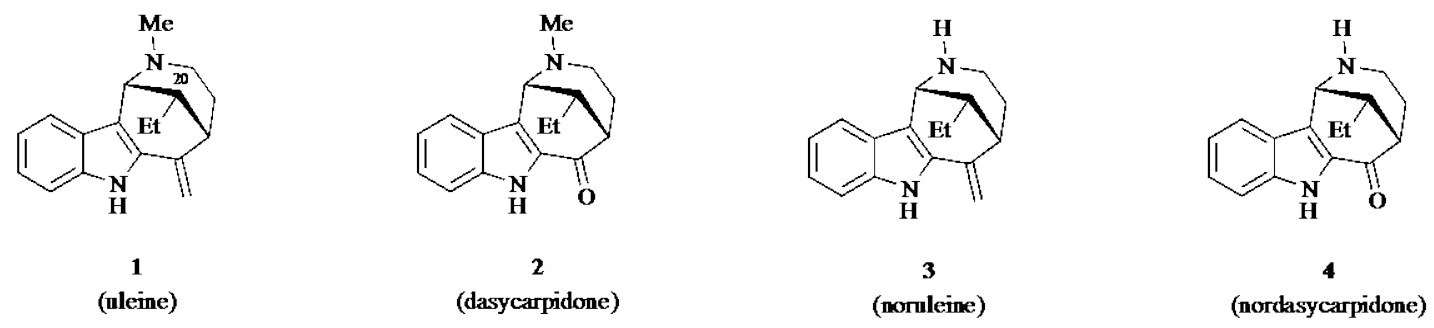

Figure 1: Structures of Uleines 1-4

A range of interesting biological properties has been attributed to uleine and its congeners. These include analgesic, anti-inflammatory, bactericidal, anti-malarial and acetylcholinesterase (AChE)-inhibiting activities. ${ }^{6}$ In addition, the capacity of compound 1 to promote the synthesis of nitric oxide has prompted investigations on the use of the source plants as adjuvants in the treatment of patients with compromised immune systems. $^{7}$

Since the completion of the key studies ${ }^{2,4,8}$ on the elucidation of the structures of the uleines, there have been numerous reports on the development of often ingenious total syntheses of compounds 1-4. ${ }^{9,10}$ These have delivered both racemic and enantiomerically 
enriched forms of the target compounds. The presence of the 1,5methanoazocino[4,3- $b$ ]indole framework within other alkaloids has also prompted the more general development of approaches to this scaffold. ${ }^{11}$ As part of our own efforts in the area, in 2012 we described ${ }^{10 f}$ a Raney-cobalt-mediated tandem reductive cyclization route to this framework and the elaboration of it to the ABCDE-ring system of the Strychnos alkaloids. This work was an extension of slightly earlier studies on the application of related processes to the assembly of the Aspidosperma alkaloids limaspermidine and 1-acetylaspidoalbidine ${ }^{12}$ that also exploited the capacity of the palladium-catalyzed Ullmann cross-coupling reaction ${ }^{13}$ to generate the relevant substrates for the reductive cyclization events.

Herein we report the extension of our earlier studies ${ }^{10 f}$ to the quite distinct and stereocontrolled total syntheses of the racemic forms of uleine, dasycarpidone, noruleine and nordasycarpidone. We also identify seemingly straightforward means by which this work could be extended to the enantioselective assembly of these same alkaloids.

\section{RESULTS AND DISCUSSION}

The reaction sequence leading to the substrate required for the pivotal tandem reductive cyclisation event is shown in Scheme 1. Thus, 4-ethylcyclohexanone (5) was converted into the corresponding (and racemic) unsaturated analogue $6(60 \%)^{14}$ by treating the former compound with iodoxybenzoic acid (IBX) in DMSO under conditions defined by Nicoloau and co-workers. ${ }^{15}$ Nucleophilic cyclopropanation of the latter compound could be achieved using the Corey-Chaykovsky ylide that had been generated in situ by well- 
established methods. ${ }^{16}$ As a result the diastereoselective formation of the bicyclo[4.1.0]heptanone 7 (80\%) was achieved although the presence of a ca. $10 \%$ of an isomeric material (presumably the corresponding cis-compound) was evident in the ${ }^{13} \mathrm{C}$ NMR spectrum of this material. Treament of compound 7 with sodium iodide in formic acid resulted in a homoconjugate addition reaction ${ }^{17}$ and formation of ca. 10:1 mixture of the desired iodomethylated product 8 (85\%) and a chromatographically inseparable isomer. The substitution of the iodine within compound $\mathbf{8}$ by a nitrile residue could not be achieved directly by, for example, treating it with sodium cyanide. Rather, a 3-(enolexo)exo-tet cyclisation reaction ${ }^{18}$ took place under all conditions employed and thus regenerating the precursor cyclopropane 7. Accordingly, and in a telescoped-type reaction sequence, compound $\mathbf{8}$ was converted into the corresponding dimethyl ketal that could now be engaged in the desired nucleophilic substitution reaction with sodium cyanide. The ensuing dimethyl ketal of the required nitrile was immediately treated with aqueous hydrochloric acid and thereby affording the targeted compound $\mathbf{9}$ in $88 \%$ yield over the three steps involved. Various attempts to effect the direct conversion of enone $\mathbf{6}$ into nitrile 9, including through addition of the acetonitrile anion to the former compound, all failed.

Dehydrogenation of cyclohexanone 9 could be achieved with some levels of regiocontrol using IBX in $\mathrm{DMSO}^{15}$ and the 4,5-disubstituted-2-cyclohexen-1-one $\mathbf{1 0}$ was thus obtained in 56\% yield. Even after chromatographic purification, this material contained IBX-derived impurities. There was also some evidence for the co-production of minor amounts of the regioisomeric enone. The (albeit modest) regioselectivity observed in this 
conversion is presumably the result of the steric effects exerted by the cyanomethyl group in substrate 9. In anticipation of perfoming a palladium-catalyzed Ullmann crosscoupling reaction, ${ }^{13}$ cyclohexenone $\mathbf{1 0}$ was subjected to a Johnson-type $\alpha$-iodination reaction ${ }^{19}$ and thus affording the iodo-derivative $\mathbf{1 1}(81 \%)$ that was readily obtained in spectroscopically pure form after flash chromatography. The pivotal cross-coupling of compound 11 with o-iodonitrobenzene proceeded smoothly when a DMSO solution of the two reaction partners was treated with copper powder and $\mathrm{Pd}_{2}(\mathrm{dba})_{3}$ (ca. 8 mole \% wrt 11) and the ensuing mixture heated at $90{ }^{\circ} \mathrm{C}$ for $0.66 \mathrm{~h}$. As a result, and after chromatographic purification, the crystalline product 12 was obtained in $81 \%$ yield.
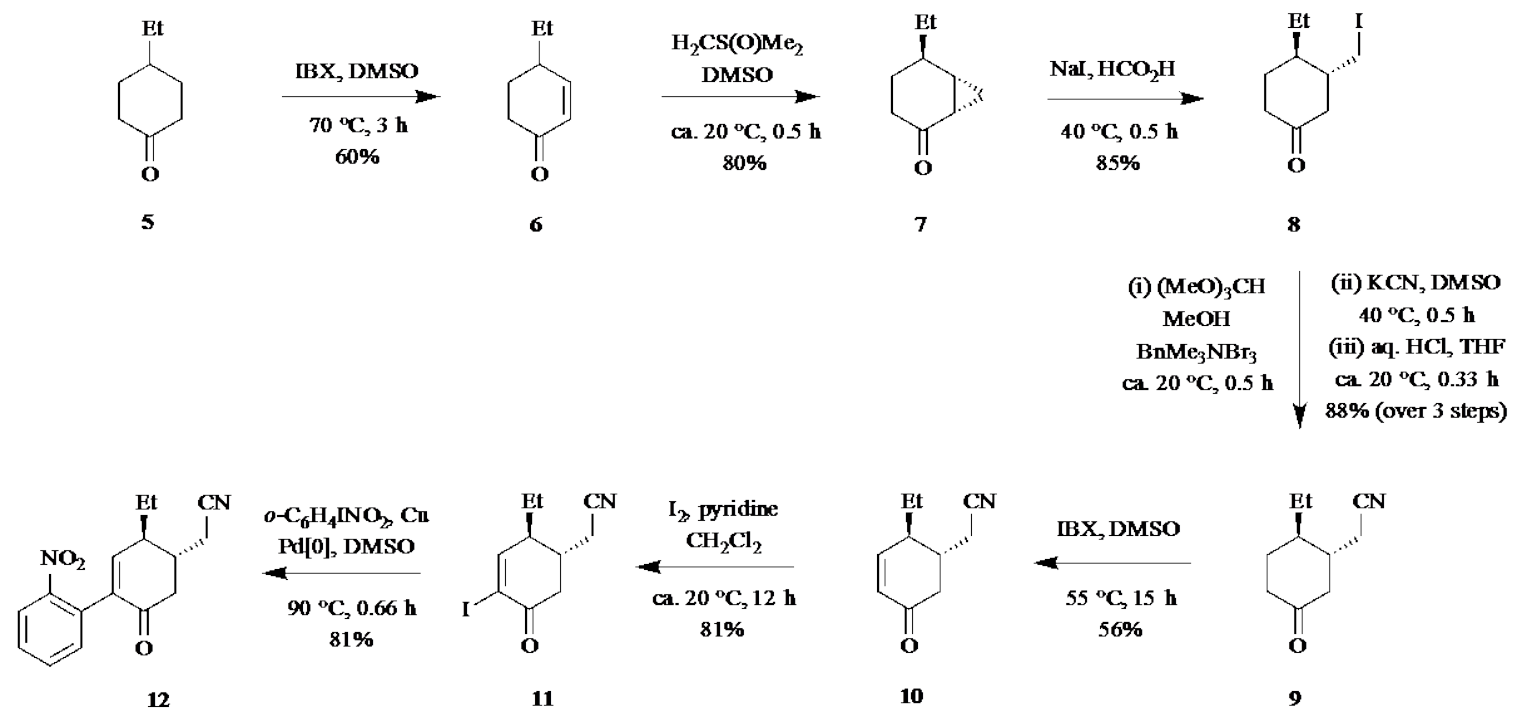

Scheme 1: Synthesis of Substrate 12 Required for the Tandem Reductive Cyclization Reaction

All of the conventional spectroscopic data acquired on compound $\mathbf{1 2}$ were in complete accord with the assigned structure but final confirmation of this followed from a single- 
crystal X-ray analysis, some details of which are provided in the Experimental Section and the Supporting Information. Most importantly, this analysis confirmed the transrelationship between the ethyl and cyanomethyl residues within the compound. Such a relationship was essential for establishing the correct relative stereochemistry of the ethyl group at C-20 in target $\mathbf{1}$ (a vexed issue encountered in a number of earlier synthetic studies $\left.{ }^{9 \mathrm{c}}\right)$.

With compound $\mathbf{1 2}$ to hand, its capacity to engage in the pivotal tandem reductive cyclisation reaction could be explored. When a THF/methanol solution of compound 12 containing $p$-toluenesulfonic acid monohydrate $\left(p-\mathrm{TsOH} \bullet \mathrm{H}_{2} \mathrm{O}\right.$ - introduced to suppress intermolecular reductive alkylation reactions) was treated with 200 wt \% of freshly prepared Raney cobalt ${ }^{20}$ and exposed to an atmosphere of hydrogen gas then the desired transform took place and such that after chromatographic purification the anticipated 1,5methanoazocino[4,3- b]indole $\mathbf{1 3}$ was obtained in 55\% yield (Scheme 2). The modest yields observed during this conversion are attributed to the rather unstable nature of the product and, for example, the apparent ready propensity of it to oxidise on standing. All of the spectral data acquired on compound $\mathbf{1 3}$ were in accord with the assigned structure but final confirmation of this followed from a single-crystal X-ray analysis of a Bocderivative (see below).
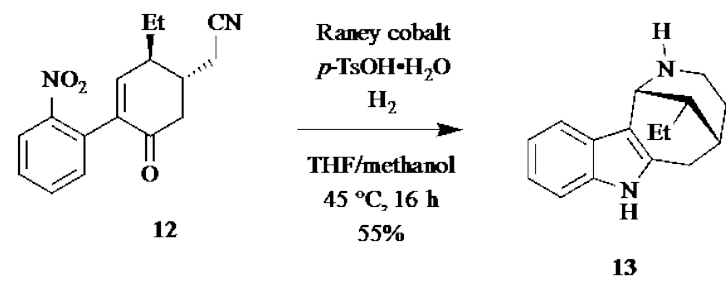


\section{Scheme 2: The Pivotal Tandem Reductive Cyclization Reaction}

Interestingly, compound $\mathbf{1 3}$ has served as an advanced intermediate in a total synthesis of the Strychnos alkaloid tubotaiwine reported by Bosch and co-workers. ${ }^{11 a}$

The route used in elaborating compound 13 to noruleine (3) and then, through $\mathrm{N}$ methylation, to uleine (1) is shown in Scheme 3 . So, the $2^{\circ}$-amine $\mathbf{1 3}$ was first converted into the corresponding Boc-derivative 14 (80\%), the structure of which was confirmed through a single-crystal X-ray analysis (see Experimental Section and the Supporting Information for some details). In $\mathrm{CDCl}_{3}$ solutions at room temperature, this material existed as a ca. 1:1 mixture of rotamers. Upon treating a dichloromethane solution of carbamate 14 with pyridinium chlorochromate (PCC), a relatively smooth oxidation reaction took place to deliver ketone $\mathbf{1 5}$ (75\%) and on reacting this with methyl lithium at $-78{ }^{\circ} \mathrm{C}$, the $3^{\circ}$-alcohol 16 was produced. This last compound was not isolated but simply treated with a ca. four-fold excess of trifluoroacetic acid at ambient temperature. As a result, both dehydration and cleavage of the Boc-group took place (no specific order of events implied). After work up and chromatographic purification then noruleine (3) was obtained in $75 \%$ yield. 


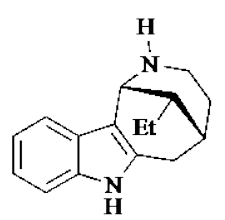

13
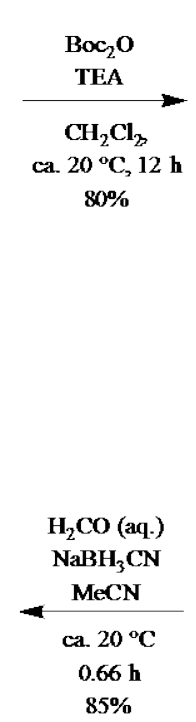

1

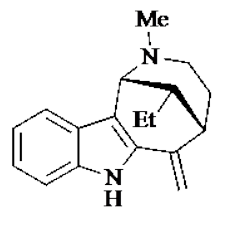

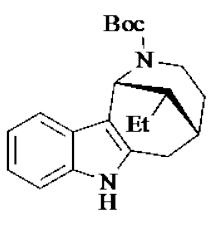

14

Scheme 3: Elaboration of the Tandem Reductive Cyclization Product 13 to Noruleine (3) and Uleine (1)

A comparison of the ${ }^{1} \mathrm{H}$ and ${ }^{13} \mathrm{C}$ NMR spectral data acquired on this material with those recorded by Patir and Ertürk ${ }^{9 e}$ on their (synthetically derived) material revealed an excellent match (see Table 1 for comparisons of the ${ }^{13} \mathrm{C}$ NMR data sets). 
Table 1: Comparison of the ${ }^{13}$ C NMR Data Recorded for Synthetically-derived Compounds 3 and 1 with those Reported for Noruleine (3) and Uleine (1)

\begin{tabular}{|c|c|c|c|}
\hline $\begin{array}{c}{ }^{13} \text { C NMR Data for } \\
\text { Compound 3 } \\
\left(\delta_{\mathrm{C}}\right)^{\mathrm{a}}\end{array}$ & $\begin{array}{c}{ }^{13} \mathrm{C} \text { NMR Data for } \\
\text { Noruleine } \\
\left(\delta_{\mathrm{C}}\right)^{\mathrm{b}}\end{array}$ & $\begin{array}{c}{ }^{13} \mathrm{C} \text { NMR Data for } \\
\text { Compound } \mathbf{1} \\
\left(\delta_{\mathrm{C}}\right)^{\mathrm{a}}\end{array}$ & $\begin{array}{c}{ }^{13} \mathrm{C} \text { NMR Data for } \\
\text { Uleine } \\
\left(\delta_{\mathrm{C}}\right)^{\mathrm{b}}\end{array}$ \\
\hline 138.7 & 138.6 & 138.7 & 138.7 \\
\hline 137.1 & 137.1 & 136.6 & 136.6 \\
\hline 134.9 & 135.0 & 135.2 & 135.2 \\
\hline 126.8 & 126.8 & 129.4 & 129.4 \\
\hline 123.0 & 122.9 & 122.8 & 122.7 \\
\hline 119.8 & 119.7 & 119.9 & 119.9 \\
\hline 118.6 & 118.5 & 119.6 & 110.7 \\
\hline 111.5 & 111.2 & 110.8 & 107.7 \\
\hline 110.9 & 110.9 & 107.7 & 106.8 \\
\hline 106.7 & 106.9 & 106.9 & $55.6^{\mathrm{c}}$ \\
\hline 49.3 & 49.3 & 56.6 & 46.1 \\
\hline 45.8 & 45.6 & 46.3 & 46.3 \\
\hline 40.6 & 40.5 & 46.1 & 44.3 \\
\hline 37.4 & 37.3 & 44.3 & 39.5 \\
\hline 35.0 & 34.8 & 39.5 & 34.7 \\
\hline 24.6 & 24.6 & 34.7 & 24.4 \\
\hline 11.8 & 11.7 & 24.4 & 11.8 \\
\hline- & - & 11.8 & \\
\hline
\end{tabular}

${ }^{\mathrm{a}}$ spectrum recorded in $\mathrm{CDCl}_{3}$ at $100 \mathrm{MHz}$; ${ }^{\mathrm{b}}$ data obtained from reference $9 \mathrm{e}$ - spectrum recorded in $\mathrm{CDCl}_{3}$ at 125 or $150 \mathrm{MHz}$; ${ }^{\mathrm{c}}$ the difference in these $\delta_{\mathrm{C}}$ values could arise from varitions in the $\mathrm{pH}$ of the medium in which each spectrum was acquired.

The conversion of noruleine (3) into uleine (1) proved a straightforward matter and simply involved (Scheme 3) subjecting the former compound to a reductive methylation reaction using a combination of formaldehyde and sodium cyanoborohydride. By such means parent compound $\mathbf{1}$ was obtained in 85\% yield and all the derived spectral data were, once again, a good match with those reported by others (see Table 1 for example).

Completion of syntheses of nordasycarpidone (4) and dasycarpidone (2) proved equally straightforward and involved, as shown in Scheme 4, TFA-induced cleavage of compound 15 to give, in 84\% yield, the former natural product. Reductive methylation of this product (viz. 4) using formaldehyde and hydrogen gas in the presence of palladium on carbon then gave dasycarpidone (2) in 70\% yield. 


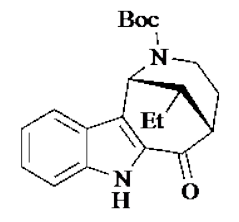

15

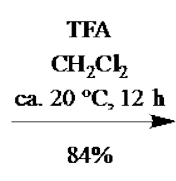

$4 \%$

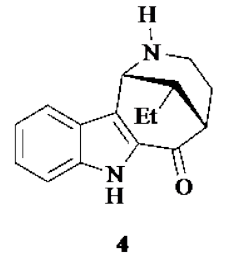

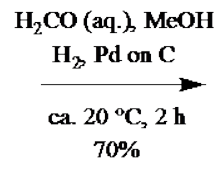

$70 \%$

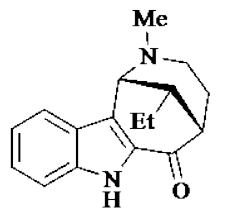

2

Scheme 4: Completion of Synthesis of Nordasycarpidon (4) and Dasycarpidone (2)

As before, all of the spectroscopic data obtained on compounds $\mathbf{2}$ and $\mathbf{4}$ were in accord with the assigned structures and, with one minor discrepancy (see Table 2), matched those reported by Bosch and co-workers. ${ }^{9 a}$

Table 2: Comparison of the ${ }^{13}$ C NMR Data Recorded for Synthetically-derived Compounds 4 and 2 with those Reported for Nordasycarpidone (4) and Dasycarpidone (2)

\begin{tabular}{|c|c|c|c|}
\hline $\begin{array}{c}{ }^{13} \text { C NMR Data for } \\
\begin{array}{c}\text { Compound } \mathbf{4} \\
\left(\delta_{\mathrm{C}}\right)^{\mathrm{a}}\end{array}\end{array}$ & $\begin{array}{c}{ }^{13} \mathrm{C} \text { NMR Data for } \\
\text { Nordasycarpidone } \\
\left(\delta_{\mathrm{C}}\right)^{\mathrm{b}}\end{array}$ & $\begin{array}{c}{ }^{13} \mathrm{C} \text { NMR Data for } \\
\text { Compound } 2 \\
\left(\delta_{\mathrm{C}}\right)^{\mathrm{a}}\end{array}$ & $\begin{array}{c}{ }^{13} \text { C NMR Data for } \\
\text { Dasycarpidone } \\
\left(\delta_{\mathrm{C}}\right)^{\mathrm{b}}\end{array}$ \\
\hline $193.2^{\mathrm{c}}$ & $193.9^{\mathrm{c}}$ & 193.2 & 193.5 \\
\hline 138.7 & 139.0 & 138.0 & 138.1 \\
\hline 132.8 & 132.9 & 132.8 & 132.9 \\
\hline 127.1 & 127.0 & 127.7 & 127.8 \\
\hline 125.1 & 125.1 & 126.8 & 126.9 \\
\hline $122.8^{\mathrm{c}}$ & $123.8^{\mathrm{c}}$ & 121.9 & 122.0 \\
\hline 121.0 & 121.0 & 121.1 & 121.1 \\
\hline 121.0 & 120.8 & 119.7 & 119.9 \\
\hline 112.9 & 113.0 & 112.6 & 112.7 \\
\hline 49.0 & 49.0 & 56.4 & 56.2 \\
\hline 48.7 & 49.0 & 49.7 & 49.6 \\
\hline 47.2 & 47.4 & 46.4 & 46.3 \\
\hline 37.2 & 37.2 & 46.1 & 46.0 \\
\hline 29.8 & 30.2 & 44.1 & 44.0 \\
\hline 25.2 & 25.0 & 30.2 & 30.1 \\
\hline 11.7 & 11.5 & 25.0 & 24.8 \\
\hline- & - & 11.8 & 11.8 \\
\hline
\end{tabular}

${ }^{\mathrm{a}}$ spectrum recorded in $\mathrm{CDCl}_{3}$ at $100 \mathrm{MHz}$; data obtained from reference $9 \mathrm{a}$ - spectrum recorded in $\mathrm{CDCl}_{3}$ at $125 \mathrm{MHz}$; ${ }^{\mathrm{c}}$ the difference in these $\delta_{\mathrm{C}}$ values could arise from varitions in the $\mathrm{pH}$ of the medium in which each spectrum was acquired. 


\section{CONCLUSION}

The work reported here, when considered in conjunction with our earlier studies, ${ }^{10 f,}$ 12,21 serves to emphasize the considerable utility of both the palladium-catalyzed Ullmann cross-coupling reaction and certain tandem reductive cyclization processes, especially when these are applied together within a given synthetic sequence. The capacity to exploit such processes in the assembly of other biologically relevant heterocyclic frameworks is the subject of ongoing studies in our laboratories.

It should also be noted that rather efficient methods for the synthesis of optically active 4substituted 2-cyclohexenones, including the $S$-enantiomer of $\mathbf{6}$, have been reported. ${ }^{22}$ Accordingly, there is every prospect that the work reported here could be applied in a straightforward manner to the enantioselective synthesis of the uleines and, perhaps even, the Strychnos alkaloids.

\section{EXPERIMENTAL SECTION}

\section{General Protocols.}

Unless otherwise specified, proton $\left({ }^{1} \mathrm{H}\right)$ and carbon $\left({ }^{13} \mathrm{C}\right)$ NMR spectra were recorded at room temperature in base-filtered $\mathrm{CDCl}_{3}$ on a spectrometer operating at 400 $\mathrm{MHz}$ for proton and $100 \mathrm{MHz}$ for carbon nuclei. The signal due to residual $\mathrm{CHCl}_{3}$ appearing at $\delta_{\mathrm{H}} 7.26$ and the central resonance of the $\mathrm{CDCl}_{3}$ "triplet" appearing at $\delta_{\mathrm{C}}$ 77.0 were used to reference ${ }^{1} \mathrm{H}$ and ${ }^{13} \mathrm{C}$ NMR spectra, respectively. ${ }^{1} \mathrm{H}$ NMR data are recorded as follows: chemical shift $(\delta)$ [multiplicity, coupling constant(s) $J(\mathrm{~Hz})$, relative integral] where multiplicity is defined as: $\mathrm{s}=$ singlet; $\mathrm{d}=$ doublet; $\mathrm{t}=$ triplet; $\mathrm{q}=$ quartet; 
$\mathrm{m}=$ multiplet or combinations of the above. Infrared spectra $\left(v_{\max }\right)$ were recorded on a FTIR Spectrometer. Samples were analyzed as thin films on KBr plates. Low-resolution ESI mass spectra were recorded on a single quadrupole liquid chromatograph-mass spectrometer, while high-resolution measurements were conducted on a time-of-flight instrument. Low- and high-resolution EI mass spectra were recorded on a magneticsector machine. Melting points were measured on an automated melting point system and are uncorrected. Analytical thin layer chromatography (TLC) was performed on aluminum-backed $0.2 \mathrm{~mm}$ thick silica gel $60 \mathrm{~F}_{254}$ plates. Eluted plates were visualized using a $254 \mathrm{~nm}$ UV lamp and/or by treatment with a suitable dip followed by heating. These dips included phosphomolybdic acid : ceric sulfate : sulfuric acid (conc.) : water (37.5 g : $7.5 \mathrm{~g}: 37.5 \mathrm{~g}: 720 \mathrm{~mL}$ ), potassium permanganate : potassium carbonate : 5\% sodium hydroxide aqueous solution : water (3 g : $20 \mathrm{~g}: 5 \mathrm{~mL}: 300 \mathrm{~mL}$ ) ), p-anisaldehyde or vanillin: sulfuric acid (conc.): ethanol (15 g : $2.5 \mathrm{~mL}$ : $250 \mathrm{~mL}$ ). Flash chromatographic separations were carried out following protocols defined by Still et al. ${ }^{23}$ with silica gel $60(40-63 \mu \mathrm{m})$ as the stationary phase and using the AR- or HPLC-grade solvents indicated. Starting materials, reagents, drying agents and other inorganic salts were generally commercially available and were used as supplied. Tetrahydrofuran (THF), methanol and dichloromethane were dried using a solvent purification system that is based upon a technology originally described by Grubbs et al. ${ }^{24}$ Where necessary, reactions were performed under an nitrogen atmosphere.

\section{Specific Chemical Transformations.}

4-Ethylcyclohex-2-en-1-one (6). A magnetically stirred solution of 4ethylcyclohexanone $(2.00 \mathrm{~g}, 15.9 \mathrm{mmol})$ in DMSO $(50 \mathrm{~mL})$ was treated with IBX $(9.10$ 
g, $32.5 \mathrm{mmol}$ ) and the resulting mixture heated at $70{ }^{\circ} \mathrm{C}$ for $3 \mathrm{~h}$ then cooled to room temperature and quenched with $\mathrm{NaHCO}_{3}$ (50 mL of a saturated aqueous solution). The ensuing mixture was filtered through diatomaceous earth and the solids thus retained washed with diethyl ether $(3 \times 20 \mathrm{~mL})$. The aqueous phase was extracted with diethyl ether $(3 \times 40 \mathrm{~mL})$ and the combined organic phases were washed with brine $(1 \times 50 \mathrm{~mL})$ before being dried $\left(\mathrm{Na}_{2} \mathrm{SO}_{4}\right)$, filtered and concentrated under reduced pressure. The ensuring black oil was subjected to flash chromatography (silica, 1:50 $\rightarrow 1: 20 \mathrm{v} / \mathrm{v}$ ethyl acetate/hexane gradient elution) and concentration of relevant fractions $\left(R_{\mathrm{f}}=0.4\right.$ in 1:7 $\mathrm{v} / \mathrm{v}$ ethyl acetate/hexane elution) afforded the title compound $\mathbf{6}^{14}(1.18 \mathrm{~g}, 60 \%)$ as a clear, colorless oil. ${ }^{1} \mathrm{H}$ NMR $\left(\mathrm{CDCl}_{3}, 400 \mathrm{MHz}\right) \delta 6.88$ (ddd, $J=10.2$, 2.6 and $1.4 \mathrm{~Hz}, 1 \mathrm{H}$ ), $5.98(\mathrm{dd}, J=10.2$ and $2.2 \mathrm{~Hz}, 1 \mathrm{H}), 2.50(\mathrm{dt}, J=16.7$ and $4.7 \mathrm{~Hz}, 1 \mathrm{H}), 2.42-2.27$ (complex m, 2H), 2.16-2.08 (complex m, 1H), 1.76-1.62 (complex m, 1H), 1.62-1.39 (complex m, 2H), 1.01 (t, $J=7.5 \mathrm{~Hz}, 3 \mathrm{H}) ;{ }^{13} \mathrm{C} \mathrm{NMR}\left(\mathrm{CDCl}_{3}, 100 \mathrm{MHz}\right) \delta 200.0,155.0$, 129.0, 37.7, 37.0, 28.2, 27.5, 11.4; IR $v_{\max }$ 2963, 1683, 1461, 1390, 1148, 942, 854, 742 $\mathrm{cm}^{-1}$; MS (ESI, +ve) m/z 125 [(M + H) $\left.)^{+}, 100 \%\right]$; HRMS $(\mathrm{M}+\mathrm{Na})^{+}$calcd for $\mathrm{C}_{8} \mathrm{H}_{12} \mathrm{NaO}$ 147.0786, found 147.0787.

rac-(1S,5R,6S)-5-Ethylbicyclo[4.1.0]heptan-2-one (7). A magnetically stirred suspension of $\mathrm{NaH}(82 \mathrm{mg}, 3.4 \mathrm{mmol})$ in dry DMSO $(10 \mathrm{~mL})$ was treated with $\mathrm{Me}_{3} \mathrm{SOI}$ (441 mg, $2.0 \mathrm{mmol}$ ) and after being maintained at room temperature for $0.17 \mathrm{~h}$ the reaction mixture was warmed to $50{ }^{\circ} \mathrm{C}$ and stirred for a further $0.34 \mathrm{~h}$. The cooled mixture was treated with enone 6 (224 mg, $1.8 \mathrm{mmol}$ ) then stirred at room temperature for $0.5 \mathrm{~h}$ before being quenched with $\mathrm{H}_{2} \mathrm{O}(15 \mathrm{~mL}$ ) and extracted with ethyl acetate ( $3 \times$ $20 \mathrm{~mL})$. The combined organic phases were washed with brine $(1 \times 50 \mathrm{~mL})$ then dried 
$\left(\mathrm{Na}_{2} \mathrm{SO}_{4}\right)$, filtered and concentrated under reduced pressure. The ensuing yellow oil was subjected to flash chromatography (silica, $1: 15 \rightarrow 1: 10 \mathrm{v} / \mathrm{v}$ ethyl acetate/hexane gradient elution) and concentration of relevant fractions ( $R_{\mathrm{f}}=0.3$ in $1: 7 \mathrm{v} / \mathrm{v}$ ethyl acetate/hexane) afforded a ca. 10:1 mixture of the title compound 7 and the diastereoisomeric cyclopropane (224 mg, 90\%) as a clear, colorless oil. ${ }^{1} \mathrm{H}$ NMR $\left(\mathrm{CDCl}_{3}, 400 \mathrm{MHz}\right) \delta$ 2.17-2.05 (complex m, 2H), 1.93-1.83 (complex m, 1H), 1.82-1.65 (complex m, 2H), 1.66-1.32 (complex m, 4H), 1.27-1.09 (complex m, 2H), 0.97 (t, $J=7.5 \mathrm{~Hz}, 3 \mathrm{H}) ;{ }^{13} \mathrm{C}$ NMR $\left(\mathrm{CDCl}_{3}, 100 \mathrm{MHz}\right) \delta 209.8,33.5,33.1,27.4,25.5,24.2,23.8,12.8,12.0$; IR $v_{\max }$ 2960, 1686, 1462, 1345, 1246, 1197, 939, 883, $824 \mathrm{~cm}^{-1}$; MS (ESI, +ve) m/z $161[(\mathrm{M}+$ $\left.\mathrm{Na})^{+}, 3 \%\right], 139\left[(\mathrm{M}+\mathrm{H})^{+}, 100\right]$; HRMS $(\mathrm{M}+\mathrm{Na})^{+}$calcd for $\mathrm{C}_{9} \mathrm{H}_{14} \mathrm{NaO}$ 161.0942, found 161.0939.

rac-(3R,4R)-4-Ethyl-3-(iodomethyl)cyclohexan-1-one $\quad(8) . \quad$ A magnetically stirred solution of ketone 7 (510 mg, $4.0 \mathrm{mmol})$ and $\mathrm{NaI}(2.20 \mathrm{~g}, 14.7 \mathrm{mmol})$ in $\mathrm{HCOOH}$ (10 mL) was heated at $40{ }^{\circ} \mathrm{C}$ for $0.5 \mathrm{~h}$ then cooled to room temperature and quenched with $\mathrm{H}_{2} \mathrm{O}(15 \mathrm{~mL})$. The resulting mixture was extracted with ethyl acetate $(3 \times 20 \mathrm{~mL})$ and the combined organic phases washed with $\mathrm{NaHCO}_{3}(50 \mathrm{~mL}$ of a saturated aqueous solution) and brine $(1 \times 50 \mathrm{~mL})$ before being dried $\left(\mathrm{Na}_{2} \mathrm{SO}_{4}\right)$, filtered and concentrated under reduced pressure. The ensuing yellow oil was subjected to flash chromatography (silica, $1: 18 \mathrm{v} / \mathrm{v}$ ethyl acetate/hexane elution) and concentration of relevant fractions $\left(R_{\mathrm{f}}=\right.$ 0.5 in 1:7 v/v ethyl acetate/hexane) afforded a ca. 10:1 mixture of the title compound 8 and a diastereoisomer (930 mg, 95\%) as a clear, colorless oil. ${ }^{1} \mathrm{H}$ NMR $\left(\mathrm{CDCl}_{3}, 400\right.$ MHz) $\delta 3.41$ (dd, $J=10.3$ and $4.9 \mathrm{~Hz}, 1 \mathrm{H}$ ), 3.24 (dd, $J=10.3$ and $2.9 \mathrm{~Hz}, 1 \mathrm{H}$ ), 2.46-2.25 (complex m, 4H), 2.16-2.04 (complex m, 1H), 1.73-1.40 (complex m, 3H), 1.36-1.14 
(complex m, 2H), 0.95 (t, $J=7.4 \mathrm{~Hz}, 3 \mathrm{H}) ;{ }^{13} \mathrm{C} \mathrm{NMR}\left(\mathrm{CDCl}_{3}, 100 \mathrm{MHz}\right) \delta 210.7,47.1$, 41.6, 40.9, 40.7, 28.8, 24.2, 15.2, 10.4; IR $v_{\max }$ 2960, 2873, 1716, 1461, 1427, 1318, 1218, $1177 \mathrm{~cm}^{-1}$; MS (ESI, +ve) m/z $289\left[(\mathrm{M}+\mathrm{Na})^{+}, 100 \%\right], 267$ [(M + H) $\left.{ }^{+}, 23\right]$; HRMS $(\mathrm{M}+\mathrm{Na})^{+}$calcd for $\mathrm{C}_{9} \mathrm{H}_{15} \mathrm{INaO} 289.0065$, found 289.0067 .

rac-2-[(1R,2R)-2-Ethyl-5-oxocyclohexyl]acetonitrile (9). Step i. A magnetically stirred solution of iodide 8 (1.08 g, $4.1 \mathrm{mmol})$ in anhydrous $\mathrm{MeOH}(10 \mathrm{~mL})$ was treated with trimethyl orthoformate $(480 \mu \mathrm{L}, 4.5 \mathrm{mmol})$ and benzyltrimethylammonium tribromide (30 mg, $0.08 \mathrm{mmol}$ ). The resulting mixture was stirred at room temperature for $0.5 \mathrm{~h}$ then quenched with $\mathrm{NaHCO}_{3}(10 \mathrm{~mL}$ of a saturated aqueous solution) and extracted with ethyl acetate $(3 \times 20 \mathrm{~mL})$. The combined organic phases were washed with brine $(1 \times 50 \mathrm{~mL})$ before being dried $\left(\mathrm{Na}_{2} \mathrm{SO}_{4}\right)$, filtered and concentrated under reduced pressure. The resulting yellow oil, presumed to contain the dimethyl ketal of compound 8, was immediately subjected to the reaction conditions defined in Step ii.

Step ii. A magnetically stirred solution of crude material obtained from Step i in DMSO (6 mL) was treated with KCN (480 mg, $7.4 \mathrm{mmol}$ ). The resulting solution was stirred at $40{ }^{\circ} \mathrm{C}$ for $0.5 \mathrm{~h}$ then quenched with $\mathrm{H}_{2} \mathrm{O}(15 \mathrm{~mL})$ and extracted with ethyl acetate $(3 \times 20$ $\mathrm{mL}$ ). The combined organic phases were concentrated under reduced pressure and the yellow oil thus obtained, and presumed to contain the dimethyl ketal of compound 9, was immediately subjected to the reaction conditions defined in Step iii.

Step iii. A magnetically stirred solution of the oil obtained from Step ii in THF (10 mL) was treated with $\mathrm{HCl}$ (5 mL of a $1 \mathrm{M}$ aqueous solution) (CAUTION: possibility of HCN generation) and the resulting mixture stirred at room temperature for $0.33 \mathrm{~h}$ before being quenched with $\mathrm{NaHCO}_{3}$ (20 mL of a saturated aqueous solution) then extracted with 
ethyl acetate $(3 \times 20 \mathrm{~mL})$. The combined organic phases were washed with brine $(1 \times 50$ $\mathrm{mL})$ then dried $\left(\mathrm{Na}_{2} \mathrm{SO}_{4}\right)$, filtered and concentrated under reduced pressure. The ensuing yellow oil was subjected to flash chromatography (silica, 1:9 v/v ethyl acetate/hexane elution) and concentration of relevant fractions ( $R_{\mathrm{f}}=0.2$ in $1: 3 \mathrm{v} / \mathrm{v}$ ethyl acetate/hexane) afforded the title compound 9 (590 mg, 88\%) as a clear, colorless oil. ${ }^{1} \mathrm{H} \mathrm{NMR}\left(\mathrm{CDCl}_{3}\right.$, $400 \mathrm{MHz}$ ) $\delta 2.50$ (dd, $J=17.1$ and $6.3 \mathrm{~Hz}, 1 \mathrm{H}$ ), 2.45-2.25 (complex m, 5H), 2.13-2.03 (complex m, 1H), 1.93-1.85 (complex m, 1H), 1.66-1.59 (complex m, 2H), 1.49-1.32 (complex m, 1H), 1.31-1.15 (complex m, 1H), 0.90 (t, $J=7.3 \mathrm{~Hz}, 3 \mathrm{H}$ ); ${ }^{13} \mathrm{C}$ NMR $\left(\mathrm{CDCl}_{3}, 100 \mathrm{MHz}\right) \delta 209.2,117.5,45.6,40.4,39.9,38.3,29.1,24.5,21.9,10.5 ;$ IR $v_{\max }$ 2964, 2877, 2245, 1715, 1464, 1426, 1328, 1250, 1193, 954, $853 \mathrm{~cm}^{-1}$; MS (ESI, +ve) m/z $188\left[(\mathrm{M}+\mathrm{Na})^{+}, 45 \%\right], 188\left[(\mathrm{M}+\mathrm{H})^{+}, 30\right], 122(100)$; HRMS $(\mathrm{M}+\mathrm{Na})^{+}$calcd for $\mathrm{C}_{10} \mathrm{H}_{15} \mathrm{NNaO}$ 188.1051, found 188.1052.

rac-2-[(1R,2S)-2-Ethyl-5-oxocyclohex-3-en-1-yl]acetonitrile

(10). A magnetically stirred solution of ketone 9 (280 mg, $1.7 \mathrm{mmol})$ in DMSO $(10 \mathrm{~mL})$ was treated with $p-\mathrm{TsOH} \cdot \mathrm{H}_{2} \mathrm{O}(90 \mathrm{mg}, 0.5 \mathrm{mmol})$ and $\mathrm{IBX}(960 \mathrm{mg}, 3.4 \mathrm{mmol})$ then heated at $55{ }^{\circ} \mathrm{C}$ for $15 \mathrm{~h}$. The cooled reaction mixture was quenched with $\mathrm{NaHCO}_{3}(15 \mathrm{~mL}$ of a saturated aqueous solution) then filtered through a pad of diatomaceous earth. The solids thus retained were washed with ethyl acetate $(3 \times 20 \mathrm{~mL})$ and the separated aqueous phase associated with the filtrate was extracted with ethyl acetate $(3 \times 40 \mathrm{~mL})$. The combined organic phases washed with brine $(1 \times 50 \mathrm{~mL})$ then dried $\left(\mathrm{Na}_{2} \mathrm{SO}_{4}\right)$, filtered and concentrated under reduced pressure. The yellow oil thus obtained was subjected to flash chromatography (silica, 1:9 $\rightarrow$ 1:4 v/v ethyl acetate/hexane gradient elution) and concentration of relevant fractions ( $R_{\mathrm{f}}=0.3$ in $1: 3 \mathrm{v} / \mathrm{v}$ ethyl acetate/hexane) afforded the 
title compound 10 (150 mg, 56\%) as a clear, colorless oil. ${ }^{1} \mathrm{H} \mathrm{NMR}\left(\mathrm{CDCl}_{3}, 400 \mathrm{MHz}\right) \delta$ 6.81 (dd, $J=10.2$ and $2.9 \mathrm{~Hz}, 1 \mathrm{H}$ ), 6.00 (dd, $J=10.2$ and $2.1 \mathrm{~Hz}, 1 \mathrm{H}$ ), 2.58 (dd, $J=16.2$ and $4.0 \mathrm{~Hz}, 1 \mathrm{H}), 2.46(\mathrm{t}, J=6.0 \mathrm{~Hz}, 2 \mathrm{H}), 2.42-2.21($ complex m, 3H), 1.73-1.63 (complex m, 1H), 1.59-1.43 (complex m, 1H), 0.94 (t, $J=7.5 \mathrm{~Hz}, 3 \mathrm{H}) ;{ }^{13} \mathrm{C}$ NMR $\left(\mathrm{CDCl}_{3}, 100 \mathrm{MHz}\right) \delta 197.1,152.4,129.3,117.5,41.5,40.9,34.9,24.4,21.6,10.4$; IR $v_{\max }$ 2966, 2257, 1679, 1389, 1249, 868, $504 \mathrm{~cm}^{-1}$; MS (ESI, +ve) m/z $186\left[(\mathrm{M}+\mathrm{Na})^{+}\right.$, 100\%]; HRMS (M + Na) ${ }^{+}$calcd for $\mathrm{C}_{10} \mathrm{H}_{13} \mathrm{NNaO} 186.0895$, found 186.0897 .

rac-2-[(1R,2S)-2-Ethyl-4-iodo-5-oxocyclohex-3-en-1-yl]acetonitrile (11). A magnetically stirred solution of enone $\mathbf{1 0}(140 \mathrm{mg}, 0.48 \mathrm{mmol})$ in $\mathrm{CH}_{2} \mathrm{Cl}_{2} /$ pyridine (4 mL of a $1: 1 \mathrm{v} / \mathrm{v}$ mixture) maintained at room temperature was treated dropwise with a solution of molecular iodine (330 mg, $1.20 \mathrm{mmol}$ ) in $\mathrm{CH}_{2} \mathrm{Cl}_{2} /$ pyridine $(4 \mathrm{~mL}$ of a 1:1 v/v mixture). The ensuing solution was stirred at room temperature for $12 \mathrm{~h}$ then treated with $\mathrm{H}_{2} \mathrm{O}(10 \mathrm{~mL})$. The separated aqueous phase was extracted with $\mathrm{CH}_{2} \mathrm{Cl}_{2}(3 \times 15 \mathrm{~mL})$ and the combined organic phases were washed, sequentially, with $\mathrm{HCl}(1 \times 20 \mathrm{~mL}$ of a $1 \mathrm{M}$ aqueous solution), $\mathrm{Na}_{2} \mathrm{~S}_{2} \mathrm{O}_{3}(1 \times 20 \mathrm{~mL}$ of a $10 \% \mathrm{w} / \mathrm{w}$ aqueous solution $)$ and brine $(1 \times$ $20 \mathrm{~mL}$ ) before being dried $\left(\mathrm{Na}_{2} \mathrm{SO}_{4}\right)$, filtered and concentrated under reduced pressure. The yellow oil thus obtained was subjected to flash chromatography (silica, 1:6 $\rightarrow$ 1:3 $\mathrm{v} / \mathrm{v}$ ethyl acetate/hexane gradient elution) and concentration of relevant fractions $\left(R_{\mathrm{f}}=\right.$ 0.4 in 1:3 v/v ethyl acetate/hexane) afforded the title compound $\mathbf{1 1}(190 \mathrm{mg}, 81 \%)$ as a clear, colorless oil. ${ }^{1} \mathrm{H}$ NMR $\left(\mathrm{CDCl}_{3}, 400 \mathrm{MHz}\right) \delta 7.63(\mathrm{~d}, J=3.2 \mathrm{~Hz}, 1 \mathrm{H}), 2.90$ (dd, $J=$ 16.3 and $4.1 \mathrm{~Hz}, 1 \mathrm{H}$ ), 2.72-2.49 (complex m, 4H), 2.46-2.33 (complex m, 1H), 1.811.71 (complex m, 1H), 1.68-1.53 (complex m, 1H), 1.04 (t, $J=7.5 \mathrm{~Hz}, 3 \mathrm{H}$ ); ${ }^{13} \mathrm{C}$ NMR $\left(\mathrm{CDCl}_{3}, 100 \mathrm{MHz}\right) \delta 190.0,160.8,117.0,103.0,45.3,40.5,35.1,24.3,21.4,10.6$; IR 
$v_{\max } 2964,2245,1686,1589,1461,1421,1329,1191,1116,948,899,772 \mathrm{~cm}^{-1}$; MS (ESI, +ve) m/z $312\left[(\mathrm{M}+\mathrm{Na})^{+}, 100 \%\right], 290\left[(\mathrm{M}+\mathrm{H})^{+}, 14\right]$; HRMS $(\mathrm{M}+\mathrm{Na})^{+}$calcd for $\mathrm{C}_{10} \mathrm{H}_{12} \mathrm{INNaO} 311.9861$, found 311.9862.

Compound 12. A magnetically stirred solution of iodide 11 (240 mg, $0.86 \mathrm{mmol})$ and o-iodonitrobenzene $(420 \mathrm{mg}, 1.7 \mathrm{mmol})$ in DMSO $(4 \mathrm{~mL})$ was treated with $\mathrm{Pd}_{2}(\mathrm{dba})_{3}(60 \mathrm{mg}, 0.07 \mathrm{mmol})$ and $\mathrm{Cu}$ powder (260 mg, 4.1 g.atom). The resulting mixture was heated at $90{ }^{\circ} \mathrm{C}$ for $0.66 \mathrm{~h}$ before being cooled to room temperature then diluted with ethyl acetate $(10 \mathrm{~mL})$. The mixture thus obtained was filtered through diatomaceous earth and the solids thus retained washed with ethyl acetate $(3 \times 10 \mathrm{~mL})$. The combined filtrates were washed with water $(2 \times 30 \mathrm{~mL})$ and the combined aqueous phases extracted with ethyl acetate $(3 \times 30 \mathrm{~mL})$. The combined organic phases were washed with brine $(1 \times 30 \mathrm{~mL})$ before being dried $\left(\mathrm{Na}_{2} \mathrm{SO}_{4}\right)$, filtered and concentrated under reduced pressure. The ensuing yellow oil was subjected to flash chromatography (silica, 1:10 $\rightarrow$ 1:5 v/v ethyl acetate/hexane gradient elution) and concentration of relevant fractions ( $R_{\mathrm{f}}=0.2$ in $1: 3 \mathrm{v} / \mathrm{v}$ ethyl acetate/hexane) afforded the title compound 12 (190 mg, 81\%) as a yellow, crystalline solid, m.p. $=109-113^{\circ} \mathrm{C} .{ }^{1} \mathrm{H}$ NMR $\left(\mathrm{CDCl}_{3}\right.$, $400 \mathrm{MHz}) \delta 8.07$ (dd, $J=8.2$ and $1.2 \mathrm{~Hz}, 1 \mathrm{H}$ ), 7.65 (td, $J=7.9$ and $1.3 \mathrm{~Hz}, 1 \mathrm{H}$ ), 7.53 (td, $J=7.9$ and $1.5 \mathrm{~Hz}, 1 \mathrm{H}$ ), 7.36-7.18 (complex m, 1H), 6.89 (d, $J=3.5 \mathrm{~Hz}, 1 \mathrm{H}$ ), 2.81 (dd, $J$ = 16.1 and $4.0 \mathrm{~Hz}, 1 \mathrm{H}), 2.76-2.43$ (complex m, 5H), 1.95-1.78 (complex m, 1H), 1.761.67 (complex m, 1H), 1.11 (t, $J=7.5 \mathrm{~Hz}, 3 \mathrm{H}) ;{ }^{13} \mathrm{C} \mathrm{NMR}\left(\mathrm{CDCl}_{3}, 100 \mathrm{MHz}\right) \delta 193.9$, 148.5, 148.0, 139.3, 133.6, 131.6, 131.3, 129.3, 124.5, 117.6, 41.3, 41.2, 34.8, 24.9, 21.6, 10.8; IR $v_{\max } 2971,2245,1683,1524,1353,1184,854,788 \mathrm{~cm}^{-1}$; MS (ESI, +ve) m/z 307 
$\left[(\mathrm{M}+\mathrm{Na})^{+}, 100 \%\right], 285\left[(\mathrm{M}+\mathrm{H})^{+}, 22\right]$; HRMS $(\mathrm{M}+\mathrm{Na})^{+}$calcd for $\mathrm{C}_{16} \mathrm{H}_{16} \mathrm{~N}_{2} \mathrm{NaO}_{3}$ 307.1059, found 307.1059.

Compound 13. A magnetically stirred solution of nitrile 12 (200 mg, $0.70 \mathrm{mmol})$, p-TsOH $\bullet \mathrm{H}_{2} \mathrm{O}$ (700 mg, $3.7 \mathrm{mmol}$ ) and Raney-cobalt $(430 \mathrm{mg}, 200 \% \mathrm{w} / \mathrm{w})$ in THF/methanol ( $15 \mathrm{~mL}$ of a $1: 1 \mathrm{v} / \mathrm{v}$ mixture) was heated at $45^{\circ} \mathrm{C}$ for $16 \mathrm{~h}$ while being maintained under an atmosphere of hydrogen. The resulting mixture was cooled to room temperature then filtered through diatomaceous earth and the solids thus retained washed with methanol $(3 \times 20 \mathrm{~mL})$. The combined filtrates were concentrated under reduced pressure to afford a yellow oil that was subjected to flash chromatography (silica, 1:20 $\rightarrow$ 1:5 v/v methanol/dichloromethane gradient elution). Concentration of relevant fractions $\left(R_{\mathrm{f}}=0.4\right.$ in $1: 4 \mathrm{v} / \mathrm{v}$ methanol/dichloromethane) afforded the title compound $\mathbf{1 3}{ }^{9 \mathrm{a}, 11 \mathrm{a}}$ (93 mg, 55\%) as a clear, unstable yellow oil. ${ }^{1} \mathrm{H}$ NMR $\left(\mathrm{CDCl}_{3}, 400 \mathrm{MHz}\right) \delta 8.20$ (s, 1H), 7.43 (d, $J=7.6 \mathrm{~Hz}, 1 \mathrm{H}), 7.25$ (d, $J=7.5 \mathrm{~Hz}, 1 \mathrm{H}), 7.03$ (m, 2H), 2.91 (dd, $J=17.4$ and 6.6 Hz, 1H), 2.67-2.35 (complex m, 3H), 2.20 (broad s, 1H), 2.01-1.75 (complex m, 2H), 1.54 (d, $J=13.4 \mathrm{~Hz}, 2 \mathrm{H}), 1.31-1.01$ (complex m, 3H), $0.81(\mathrm{t}, J=7.4 \mathrm{~Hz}, 3 \mathrm{H}) ;{ }^{13} \mathrm{C}$ NMR $\left(\mathrm{CDCl}_{3}, 100 \mathrm{MHz}\right) \delta$ 136.3, 136.0, 126.8, 121.1, 119.4, 117.4, 110.6, 107.2, 48.8, 43.4, 37.1, 34.0, 29.9, 25.6, 24.0, 11.8; IR $v_{\max } 2958,2925,2873,1617,1456,1304,1238$, 1010, 906, $727 \mathrm{~cm}^{-1}$; MS (ESI, +ve) m/z $241\left[(\mathrm{M}+\mathrm{H})^{+}, 100 \%\right], 224$ (45), 198 (30); HRMS $(\mathrm{M}+\mathrm{H})^{+}$calcd for $\mathrm{C}_{16} \mathrm{H}_{21} \mathrm{~N}_{2} 241.1705$, found 241.1702 .

Compound 14. A magnetically stirred solution of amine 13 (87 mg, $0.36 \mathrm{mmol})$ in dichloromethane $(5 \mathrm{~mL})$ was treated with $\mathrm{Boc}_{2} \mathrm{O}(157 \mathrm{mg}, 0.72 \mathrm{mmol})$ and triethylamine (300 $\mu \mathrm{L}, 2.2 \mathrm{mmol}$ ). The ensuing mixture was stirred at room temperature for $12 \mathrm{~h}$ then quenched with $\mathrm{H}_{2} \mathrm{O}(20 \mathrm{~mL})$ and extracted with dichloromethane $(3 \times 20$ 
$\mathrm{mL})$. The combined organic phases were washed with brine $(1 \times 30 \mathrm{~mL})$ before being dried $\left(\mathrm{Na}_{2} \mathrm{SO}_{4}\right)$, filtered and concentrated under reduced pressure. The yellow oil thus obtained was subjected to flash chromatography (silica, 1:10 $\rightarrow$ 1:5 v/v ethyl acetate/hexane gradient elution) and concentration of relevant fractions $\left(R_{\mathrm{f}}=0.5\right.$ in 1:3 $\mathrm{v} / \mathrm{v}$ ethyl acetate/hexane) afforded the title compound 14 (98 $\mathrm{mg}, 80 \%)$ as a white, crystalline solid and a ca. 1:1 mixture of rotamers, m.p. $=216^{\circ} \mathrm{C} .{ }^{1} \mathrm{H}$ NMR (DMSO- $d_{6}$, $400 \mathrm{MHz}) \delta$ (mixture of rotamers) 10.91 (s, $0.5 \mathrm{H}), 10.85$ (s, $0.5 \mathrm{H}), 7.41$ (d, $J=7.6 \mathrm{~Hz}$, 1H), 7.27 (dd, $J=10.7$ and $7.8 \mathrm{~Hz}, 1 \mathrm{H}$ ), 7.02-6.89 (complex m, 2H), 5.36 (s, 0.5H), 5.27 (s, 0.5H), 3.62 (dd, $J=13.2$ and $5.5 \mathrm{~Hz}, 0.5 \mathrm{H}$ ), 3.52 (dd, $J=13.3$ and $5.7 \mathrm{~Hz}, 0.5 \mathrm{H}$ ), 2.96 (dd, $J=17.8$ and $6.7 \mathrm{~Hz}, 1 \mathrm{H}$ ), 2.60 (dd, $J=17.7$ and $13.1 \mathrm{~Hz}, 1 \mathrm{H}$ ), 2.46-2.35 (complex m, 1H), 2.25 (broad s, 1H), 1.85-1.59 (complex m, 3H), 1.52 (s, 4.5H), 1.35 (s, 4.5H), 1.25-1.10 (complex m, 2H), 0.89 (t, $J=7.4 \mathrm{~Hz}, 3 \mathrm{H}$ ); ${ }^{13} \mathrm{C}$ NMR (DMSO- $\left.d_{6}, 100 \mathrm{MHz}\right) \delta$ (mixture of rotamers) 154.6, 154.1, 136.8, 136.7, 126.9, 126.8, 120.7(1), 120.6(5), 118.8, 118.2, 117.6, 111.3, 111.1, 105.9, 105.5, 78.9, 78.6, 48.1, 46.9, 43.6, 43.2, 37.2, 36.0, 33.4, 33.2, 29.3, 28.7, 28.5, 25.0, 23.7, 23.6, 12.2, 12.1; IR $v_{\max } 3402,3301,2961,2929$, 2874, 1662, 1462, 1416, 1365, 1308, 1169, 1127, 864, $742 \mathrm{~cm}^{-1}$; MS (ESI, +ve) m/z 363 $\left[(\mathrm{M}+\mathrm{Na})^{+}, 100 \%\right], 341\left[(\mathrm{M}+\mathrm{H})^{+}\right.$, 33]; HRMS $(\mathrm{M}+\mathrm{Na})^{+}$calcd for $\mathrm{C}_{21} \mathrm{H}_{28} \mathrm{~N}_{2} \mathrm{NaO}_{2}$ 363.2048, found 363. 2047.

Compound 15. A magnetically stirred solution of compound 14 (45 mg, 0.13 mmol) in dichloromethane $(5 \mathrm{~mL})$ was treated with PCC $(57 \mathrm{mg}, 0.27 \mathrm{mmol})$ and the ensuing mixture stirred at room temperature for $0.66 \mathrm{~h}$ then quenched with iso-propanol (3 $\mathrm{mL})$. The resulting mixture was treated with water $(15 \mathrm{~mL})$ then extracted with dichloromethane $(3 \times 20 \mathrm{~mL})$. The combined organic phases were washed with brine $(1 \times$ 
$30 \mathrm{~mL}$ ) before being dried $\left(\mathrm{Na}_{2} \mathrm{SO}_{4}\right)$, filtered and concentrated under reduced pressure. The ensuing yellow oil was subjected to flash chromatography (silica, 1:10 $\rightarrow$ 1:5 v/v ethyl acetate/hexane gradient elution) and concentration of relevant fractions $\left(R_{\mathrm{f}}=0.5\right.$ in 1:3 v/v ethyl acetate/hexane) afforded the title compound 15 (35 mg, 75\%) as a clear, yellow oil and a ca. 1:1 mixture of rotamers. ${ }^{1} \mathrm{H}$ NMR $\left(\mathrm{CDCl}_{3}, 400 \mathrm{MHz}\right) \delta$ (mixture of rotamers) 9.89 (s, 0.5H), 9.81 (s, 0.5H), 7.95 (d, $J=8.2 \mathrm{~Hz}, 0.5 \mathrm{H}), 7.80$ (d, $J=8.1 \mathrm{~Hz}$, 0.5H), 7.53 (t, $J=9.3 \mathrm{~Hz}, 1 \mathrm{H}), 7.41$ (t, $J=7.8 \mathrm{~Hz}, 1 \mathrm{H}), 7.21$ (m, 1H), 5.85 (s, 0.5H), 5.67 (s, 0.5H), 3.99 (dd, $J=14.0$ and $5.5 \mathrm{~Hz}, 0.5 \mathrm{H}$ ), 3.79 (dd, $J=14.3$ and $5.7 \mathrm{~Hz}, 0.5 \mathrm{H}$ ), 2.86 (s, 1H), 2.79-2.60 (complex m, 1H), 2.22 (t, $J=7.3 \mathrm{~Hz}, 1 \mathrm{H}$ ), 2.15-1.87 (complex m, 2H), 1.65 (s, 4.5H), 1.45 (s, 4.5H), $1.43-1.34$ (complex m, 2H), 0.96 (t, $J=7.4 \mathrm{~Hz}$, $3 \mathrm{H}) ;{ }^{13} \mathrm{C} \mathrm{NMR}\left(\mathrm{CDCl}_{3}, 100 \mathrm{MHz}\right) \delta$ (mixture of rotamers) 193.0, 155.0, 154.3, 138.6, 132.4, 127.3, 125.4, 125.3, 123.0, 122.7, 122.3, 121.6, 121.1, 112.9, 112.5, 80.3, 79.9, 48.3, 48.1, 47.8, 47.0, 46.7, 36.9, 35.7, 31.6, 30.2, 28.7, 28.4, 24.9, 24.8, 22.7, 11.8; IR $v_{\max } 3268,2964,2932,2876,1649,1470,1407,1366,1277,1254,1154,1127,1019$, 867, $747 \mathrm{~cm}^{-1}$; MS (ESI, +ve) m/z 731 [(2M + Na) $\left.)^{+}, 100 \%\right], 377\left[(\mathrm{M}+\mathrm{Na})^{+}, 50\right] ;$ HRMS $(\mathrm{M}+\mathrm{Na})^{+}$calcd for $\mathrm{C}_{21} \mathrm{H}_{26} \mathrm{~N}_{2} \mathrm{NaO}_{3}$ 377.1841, found 377.1843.

Noruleine (3). Step i. A magnetically stirred solution of ketone 15 (14 mg, 0.04 mmol) in THF (4 mL) was cooled to $-78{ }^{\circ} \mathrm{C}$ then treated with methyllithium $(40.0 \mu \mathrm{L}$ of a 3.0 $\mathrm{M}$ solution in diethoxymethane). The resulting mixture was stirred at $-78{ }^{\circ} \mathrm{C}$ for $0.16 \mathrm{~h}$ then quenched with water $(15 \mathrm{~mL})$. After warming the resulting mixture to room temperature, the aqueous phase was extracted with dichloromethane $(3 \times 20 \mathrm{~mL})$ and the combined organic phases were washed with brine $(1 \times 30 \mathrm{~mL})$ before being dried $\left(\mathrm{Na}_{2} \mathrm{SO}_{4}\right)$, filtered and concentrated under reduced pressure. The ensuing yellow oil, 
presumed to contain the anticipated tert-alcohol, was subjected to the Step ii of the reaction sequence as described immediately below.

Step ii. A magnetically stirred solution of the yellow oil obtained from Step i in dichloromethane $(4 \mathrm{~mL})$ was treated with trifluoroacetic acid $(15 \mu \mathrm{L}, 0.19 \mathrm{mmol})$. The resulting mixture was stirred at room temperature for $12 \mathrm{~h}$ then concentrated under reduced pressure to afford a yellow oil that was subjected to flash chromatography (silica, $1: 25 \rightarrow 1: 7 \mathrm{v} / \mathrm{v}$ methanol / dichloromethane gradient elution). Concentration of relevant fractions $\left(R_{\mathrm{f}}=0.5\right.$ in $1: 4 \mathrm{v} / \mathrm{v}$ methanol $/$ dichloromethane) afforded the title compound $3^{9 \mathrm{e}}$ (7.5 mg, 75\%) as a clear, yellow oil. ${ }^{1} \mathrm{H}$ NMR (CDCl $\left.3,400 \mathrm{MHz}\right) \delta 8.13$ (s, 1H), 7.51 (d, $J=7.8 \mathrm{~Hz}, 1 \mathrm{H}), 7.29$ (d, $J=7.8 \mathrm{~Hz}, 1 \mathrm{H}), 7.13$ (t, $J=7.8 \mathrm{~Hz}, 1 \mathrm{H}), 7.04$ (t, $J=7.8 \mathrm{~Hz}$, 1H), 5.20 (s, 1H), 4.93 (s, 1H), 4.32 (s, 1H), 2.89-2.36 (complex m, 3H), 2.26-1.88 (complex m, 3H), 1.60 (d, $J=12.6 \mathrm{~Hz}, 1 \mathrm{H}), 1.18-0.98$ (complex m, 2H), 0.79 (t, $J=7.4$ $\mathrm{Hz}, 3 \mathrm{H}) ;{ }^{13} \mathrm{C}$ NMR $\left(\mathrm{CDCl}_{3}, 100 \mathrm{MHz}\right) \delta$ see Table 1; IR $v_{\max }$ 3230, 2960, 2930, 1672, 1613, 1454, 1325, 1201, 1179, 1134, 906, 798, $740 \mathrm{~cm}^{-1}$; MS (ESI, +ve) m/z $253[(\mathrm{M}+$ $\mathrm{H})^{+}$, 40\%], 236 (100); HRMS (M + H) ${ }^{+}$calcd for $\mathrm{C}_{17} \mathrm{H}_{21} \mathrm{~N}_{2} 253.1705$, found 253.1701.

Uleine (1). A magnetically stirred solution of amine 3 (15 mg, $0.06 \mathrm{mmol})$ in acetonitrile $(4 \mathrm{~mL})$ was treated, sequentially, with formaldehyde $(100 \mu \mathrm{L}$ of a $35 \% \mathrm{w} / \mathrm{w}$ aqueous solution, $1.2 \mathrm{mmol})$ and $\mathrm{NaCNBH}_{3}(8 \mathrm{mg}, 0.13 \mathrm{mmol})$. The resulting mixture was stirred at room temperature for $0.66 \mathrm{~h}$ then quenched with $\mathrm{NaHCO}_{3}(10 \mathrm{~mL}$ of a saturated aqueous solution). The separated aqueous phase was extracted with dichloromethane $(3 \times 20 \mathrm{~mL})$ and the combined organic phases were washed with brine $(1 \times 30 \mathrm{~mL})$ before being dried $\left(\mathrm{Na}_{2} \mathrm{SO}_{4}\right)$, filtered and concentrated under reduced pressure. The resulting yellow oil was subjected to flash chromatography (silica, 1:25 $\rightarrow$ 
$1: 7 \mathrm{v} / \mathrm{v}$ methanol/dichloromethane gradient elution) and concentration of relevant fractions ( $R_{\mathrm{f}}=0.6$ in $1: 4 \mathrm{v} / \mathrm{v}$ methanol/dichloromethane) afforded the title compound $\mathbf{1}^{9 \mathrm{e}}$ (13 mg, 85\%) as a clear, yellow oil. ${ }^{1} \mathrm{H}$ NMR $\left(\mathrm{CDCl}_{3}, 400 \mathrm{MHz}\right) \delta 8.27(\mathrm{~s}, 1 \mathrm{H}), 7.58$ (d, $J=7.9 \mathrm{~Hz}, 1 \mathrm{H}), 7.37$ (d, $J=7.9 \mathrm{~Hz}, 1 \mathrm{H}), 7.21(\mathrm{t}, J=7.9 \mathrm{~Hz}, 1 \mathrm{H}), 7.12$ (t, $J=7.9 \mathrm{~Hz}$, 1H), 5.29 (s, 1H), 5.02 (s, 1H), 4.12 (d, $J=2.0 \mathrm{~Hz}, 1 \mathrm{H}), 2.72$ (d, $J=2.0 \mathrm{~Hz}, 1 \mathrm{H}), 2.58-$ 2.42 (complex m, 1H), 2.32 (s, 3H), 2.25-1.96 (complex m, 3H), 1.72 (d, $J=7.6 \mathrm{~Hz}$, 1H), 1.22-1.04 (complex m, 2H), 0.87 (t, $J=7.4 \mathrm{~Hz}, 3 \mathrm{H}) ;{ }^{13} \mathrm{C} \mathrm{NMR}\left(\mathrm{CDCl}_{3}, 100 \mathrm{MHz}\right)$ $\delta$ see Table 1; IR $v_{\max } 3231,2957,2926,1668,1456,1320,1050,880,738 \mathrm{~cm}^{-1}$; MS (ESI, +ve) m/z $267\left[(\mathrm{M}+\mathrm{H})^{+}\right.$, 85\%], $236(100)$; HRMS $(\mathrm{M}+\mathrm{H})^{+}$calcd for $\mathrm{C}_{18} \mathrm{H}_{23} \mathrm{~N}_{2}$ 267.1861, found 267.1860.

Nordasycarpidone (4). A magnetically stirred solution of ketone 15 (17 mg, 0.05 mmol) in dichloromethane $(4 \mathrm{~mL})$ was treated with trifluoroacetic acid $(15 \mu \mathrm{L}, 0.19$ mmol) and the ensuing mixture stirred at room temperature for $12 \mathrm{~h}$ before being concentrated under reduced pressure to afford a yellow oil. Subjection of this material to flash chromatography (silica, 1:25 $\rightarrow$ 1:7 v/v methanol/dichloromethane gradient elution) and concentration of relevant fractions $\left(R_{\mathrm{f}}=0.6\right.$ in $1: 4 \mathrm{v} / \mathrm{v}$ methanol/dichloromethane $)$ afforded the title compound $4^{9 \mathrm{a}}(10 \mathrm{mg}, 84 \%)$ as a clear, yellow oil. ${ }^{1} \mathrm{H} \mathrm{NMR}\left(\mathrm{CDCl}_{3}\right.$, $400 \mathrm{MHz}) \delta 9.89(\mathrm{~s}, 1 \mathrm{H}), 7.72(\mathrm{~d}, J=8.0 \mathrm{~Hz}, 1 \mathrm{H}), 7.45(\mathrm{~d}, J=8.0 \mathrm{~Hz}, 1 \mathrm{H}), 7.34(\mathrm{t}, J=$ $8.0 \mathrm{~Hz}, 1 \mathrm{H}$ ), 7.13 (t, $J=8.0 \mathrm{~Hz}, 1 \mathrm{H}$ ), 6.14 (broad s, 1H), 4.83 (s, 1H), 2.97 (broad s, 1H), 2.75 (s, 2H), 2.49 (s, 1H), 2.17 (m, 1H), 1.86 (d, $J=12.7 \mathrm{~Hz}, 1 \mathrm{H}$ ), 1.31-1.23 (complex m, 2H), $0.83(\mathrm{t}, J=7.4 \mathrm{~Hz}, 3 \mathrm{H}) ;{ }^{13} \mathrm{C} \mathrm{NMR}\left(\mathrm{CDCl}_{3}, 100 \mathrm{MHz}\right) \delta$ see Table 2; IR $v_{\max }$ 3255, 2960, 1654, 1541, 1474, 1328, 1199, 1132, 908, 800, 746 cm$^{-1}$; MS (ESI, +ve) m/z 
$255\left[(\mathrm{M}+\mathrm{H})^{+}, 55 \%\right], 238(100)$; HRMS $(\mathrm{M}+\mathrm{H})^{+}$calcd for $\mathrm{C}_{16} \mathrm{H}_{19} \mathrm{~N}_{2} \mathrm{O}$ 255.1497, found 255.1499 .

Dasycarpidone (2). A magnetically stirred solution of compound 4 (15 mg, 0.06 $\mathrm{mmol}$ ) in methanol (5 mL) was treated with $10 \%$ Pd on carbon (3 mg) and formaldehyde (200 $\mu \mathrm{L}$ of a 35\% w/v aqueous solution, $2.3 \mathrm{mmol}$ ). The resulting mixture was stirred at room temperature for $2 \mathrm{~h}$ while being maintained under an atmosphere of hydrogen. The mixture thus obtained was filtered through diatomaceous earth and the solids thus retained washed with methanol $(3 \times 10 \mathrm{~mL})$. The combined filtrates were diluted with water $(30 \mathrm{~mL})$ and dichloromethane $(30 \mathrm{~mL})$ and the separated aqueous phase was extracted with dichloromethane $(3 \times 30 \mathrm{~mL})$. The combined organic phases were washed with brine $(1 \times 30 \mathrm{~mL})$ before being dried $\left(\mathrm{Na}_{2} \mathrm{SO}_{4}\right)$, filtered and concentrated under reduced pressure. The yellow oil thus obtained was subjected to flash chromatography (silica, 1:25 $\rightarrow$ 1:7 $\mathrm{v} / \mathrm{v}$ methanol/dichloromethane gradient elution) and concentration of relevant fractions $\left(R_{\mathrm{f}}=0.7\right.$ in $1: 4 \mathrm{v} / \mathrm{v}$ methanol/dichloromethane) afforded the title compound $2^{9 \mathrm{a}}$ (11 mg, 70\%) as a yellow oil. ${ }^{1} \mathrm{H} \mathrm{NMR}\left(\mathrm{CDCl}_{3}, 400 \mathrm{MHz}\right) \delta 9.20(\mathrm{~s}, 1 \mathrm{H})$, $7.63(\mathrm{~d}, J=8.1 \mathrm{~Hz}, 1 \mathrm{H}), 7.41(\mathrm{~d}, J=8.1 \mathrm{~Hz}, 1 \mathrm{H}), 7.31(\mathrm{~m}, 1 \mathrm{H}), 7.12(\mathrm{~m}, 1 \mathrm{H}), 4.24$ (s, 1H), 2.63 (broad s, 1H), 2.55 (d, $J=7.0 \mathrm{~Hz}, 1 \mathrm{H}$ ), 2.32 (s, 1H), 2.27 (s, 3H), 2.15-1.94 (complex m, 2H), 1.85 (d, $J=9.7 \mathrm{~Hz}, 1 \mathrm{H}), 1.34-1.04$ (complex m, 2H), 0.82 (t, $J=7.4$ $\mathrm{Hz}, 3 \mathrm{H}) ;{ }^{13} \mathrm{C}$ NMR $\left(\mathrm{CDCl}_{3}, 100 \mathrm{MHz}\right) \delta$ see Table 2; IR $v_{\max }$ 3262, 2929, 1650, 1531, 1467, 1325, 1151, 1021, 744, $489 \mathrm{~cm}^{-1}$; MS (ESI, +ve) m/z 269 [(M + H) $\left.{ }^{+}, 73 \%\right], 238$ (100); HRMS (M + H) ${ }^{+}$calcd for $\mathrm{C}_{17} \mathrm{H}_{21} \mathrm{~N}_{2} \mathrm{O}$ 269.1654, found 269.1655. 


\section{Crystallographic Studies}

Crystallographic Data for Compound 12. $\mathrm{C}_{16} \mathrm{H}_{16} \mathrm{~N}_{2} \mathrm{O}_{2}, M=284.31, T=150 \mathrm{~K}$, orthorhombic, space group $P 2{ }_{1}{ }_{2}{ }_{1} 1, Z=4, a=8.56836(10) \AA, b=12.02612$ (14) $\AA, c=$ 14.15115(14) $\AA ; \beta=103.2795(16)^{\circ} ; V=1458.19(3) \AA^{3}, D_{x}=1.295 \mathrm{~g} \mathrm{~cm}^{-3}, 2890$ unique data $\left(2 \theta_{\max }=144.8^{\circ}\right), R=0.027$ [for 2828 reflections with $I>2.0 \sigma(I)$ ]; $R w=0.069$ (all data), $S=1.0$.

Crystallographic Data for Compound 14. $\mathrm{C}_{21} \mathrm{H}_{28} \mathrm{~N}_{2} \mathrm{O}_{2}, M=340.47, T=150 \mathrm{~K}$, monoclinic, space group $P 2{ }_{1} / n, Z=4, a=10.1738(2) \AA, b=10.6826(1) \AA, c=17.3464(3)$ $\AA ; V=1834.84(5) \AA^{3}, D_{x}=1.232 \mathrm{~g} \mathrm{~cm}^{-3}, 3623$ unique data $\left(2 \theta_{\max }=144.6^{\circ}\right), R=0.031$ for 3271 reflections with $I>2.0 \sigma(I)]$; $R w=0.075$ (all data), $S=0.99$.

Structure Determinations. Images were measured on a diffractometer $(\mathrm{Cu} \mathrm{K \alpha}$, mirror monochromator, $\lambda=1.54184 \AA$ ) fitted with an area detector and data extracted using the CrysAlis package. ${ }^{25}$ Structure solution was by direct methods (SIR92). ${ }^{26}$ The structures of compounds 12 and 14 were refined using the CRYSTALS program package. ${ }^{27}$ Atomic coordinates, bond lengths and angles, and displacement parameters for compounds 12 and 14 have been deposited at the Cambridge Crystallographic Data Centre (CCDC nos. 1450903 and 1450904). These data can be obtained free-of-charge via www.ccdc.cam.ac.uk/data_request/cif, by emailing data_request@ccdc.cam.ac.uk, or by contacting The Cambridge Crystallographic Data Centre, 12 Union Road, Cambridge CB2 1EZ, UK; fax: +44 1223336033. 


\section{ASSOCIATED CONTENT}

\section{Supporting Information}

Crystallographic data (CIF); anisotropic displacement ellipsoid plot derived from the single-crystal analyses of compounds 12 and 14; ${ }^{1} \mathrm{H}$ and ${ }^{13} \mathrm{C}$ NMR spectra for compounds 1-4 and 6-15. This material is available free of charge via the Internet at http://pubs.acs.org.

\section{AUTHOR INFORMATION}

\section{Corresponding Author}

*E-mail: Martin.Banwell@anu.edu.au

\section{Notes}

The authors declare no competing financial interest.

\section{ACKNOWLEDGEMENTS}

We thank the Australian Research Council and the Instiute of Advanced Studies for financial support. FT is the grateful recipient of a CSC PhD Scholarship provided by the Government of the People’s Republic of China.

\section{REFERENCES}


1. Joule, J. A. in Indoles, Saxton, J. E., Ed. In The Chemistry of Heterocyclic Compounds, Weissberger, A.; Taylor, E. C. Eds.; Wiley, New York 1983, Vol. 25, Part 4, pp 265-292.

2. Schmutz, J.; Hunziker, F.; Hirt, R. Helv. Chim. Acta 1957, 40, 1189.

3. Joule, J. A.; Ohashi, M.; Gilbert, B.; Djerassi, C. Tetrahedron 1965, 21, 1717.

4. See, for example, Gaskell, A. J.; Joule, J. A. Chem. Ind. (London) 1967, 1089.

5. Miranda, E. C.; Blechert, S. Tetrahedron Lett. 1982, 23, 5395.

6. (a) Seidl, C.; Correia, B. L.; Stinghen, A. E. M.; Santos, C. A. M. Z. Naturforsch. 2010, 65c, 440; (b) dos Santos Torres, Z. E.; Silveira, E. R.; Rocha e Silva, L. F.; Lima, E. S.; Carvalho de Vasconcellos, M.; Uchoa, D. E. de A.; Filho, R. B.; Pohlit, A. M. Molecules 2013, 18, 6281; (c) Chierrito, T. P. C.; Aguiar, A. C. C.; de Andrade, I. M.; Ceravolo, I. P.; Gonçalves, R. A. C.; de Oliveira, A. J. B.; Krettli, A. U. Malaria J. 2014, 13, 142; (d) Uludag, N.; Yakup, M. Org. Prep. Proced. Int. 2015, 47, 454 and references cited therein.

7. Maes, D.; Maes, R. Rev. Bras. Farmacogn. 2015, 25, 42.

8. (a) Büchi, G.; Warnhoff, E. W. J. Am. Chem. Soc. 1959, 81, 4433; (b) Shamma, M.; Weiss, J. A.; Shine, R. J. Tetrahedron Lett. 1967, 2489. Also see (c) Borris, R. P.; Lankin, D. C.; Cordell, G. A. J. Nat. Prod. 1983, 46, 200.

9. See, for example, (a) Gracia, J.; Casamitjana, N.; Bonjoch, J.; Bosch, J. J. Org. Chem. 1994, 59, 3939 and references cited therein; (b) Saito, M.; Kawamura, M.; Hiroya, K.; Ogasawara, K. Chem. Commun. 1997, 765; (c) Schmitt, M. H.; Blechert, S. Angew. Chem. Int. Ed. 1997, 36, 1474; (d) Bennasar, M.-L.; Roca, T.; 
García-Díaz, D. J. Org. Chem. 2008, 73, 9033; (e) Patir, S.; Ertük, E. Org. Biomol. Chem. 2013, 11, 2804.

10. For studies on the synthesis of the tetracyclic framework of the uleine alkaloids see: (a) Feliz, M.; Bosch, J.; Mauleón, D.; Amat, M.; Domingo, A. J. Org. Chem. 1982, 47, 2435; (b) Bonjoch, J.; Casamithana, N.; Gracia, J.; Bosch, J. Tetrahedron Lett. 1989, 30, 5659; (c) Rubiralta, M.; Torrens, A.; Reig, I.; Grierson, D. S.; Husson, H.-P. Heterocycles 1989, 29, 2121; (d) Micouin, L.; Diez, A.; Castells, J.; López, D.; Rubiralta, M.; Quirion, J.-C.; Husson, H.-P. Tetrahedron Lett. 1995, 36, 1693; (e) Uludag, N.; Uyar, T.; Patir, S. Org. Prep. Proced. Int. 2003, 35, 397; (f) Reekie, T. A.; Banwell, M. G.; Willis, A. C. J. Org. Chem. 2012, 77, 10773; (g) see ref. 6d.

11. (a) Gracia, J.; Bonjoch, J.; Casmitjana, N.; Amat, M.; Bosch, M. J. Chem. Soc., Chem. Commun. 1991, 614; (b) Magnus, P.; Sear, N. L.; Kim, C. S.; Vicker, N. J. Org. Chem., 1992, 57, 70; (c) Jiricek, J.; Blechert, S. J. Am. Chem. Soc. 2004, 126, 3534; (d) Martin, C. L.; Nakamura, S.; Otte, R.; Overman, L. E. Org. Lett. 2011, 13, 138.

12. Tan, S. H.; Banwell, M. G.; Willis, A. C.; Reekie, T. A. Org. Lett. 2012, 14, 5621.

13. Banwell, M. G.; Jones, M. T.; Reekie, T. A. Chemistry in New Zealand 2011, 75, 122.

14. (a) Ergün, Y.; Bayraktar, N.; Patir, S.; Okay, G. J. Heterocyclic Chem. 2000, 37, 11; (b) Tokunaga, M.; Harad, S.; Iwasawa, T.; Obora, Y.; Tsuji, Y. Tetrahedron Lett. 2007, 48, 6860. 
15. Nicolaou, K. C.; Montagnon, T.; Baran, P. S.; Zhong, Y.-L. J. Am. Chem. Soc., 2002, 124, 2245.

16. Corey, E. J.; Chaykovsky, M. J. Am. Chem. Soc. 1965, 87, 1353.

17. For other examples of such processes see: (a) Demuth, M.; Raghavan, P. R. Helv. Chem. Acta 1979, 62, 2338; (b) Wong, H. N. C.; Hon, M.-Y.; Tse, C.-W.; Yip, Y.-C. Chem. Rev. 1989, 89, 165; (c) Jiang, X.; Lim, Z.; Yeumg, Y.-Y. Tetrahedron Lett. 2013, 54, 1798.

18. Baldwin, J. E.; Lusch, M. J. Tetrahedron 1982, 38, 2939 and references cited therein.

19. Johnson, C. R.; Adams, J. P.; Braun, M. P.; Senanayake, C. B. W.; Wovkulich, P. M.; Uskokovic, M. R. Tetrahedron Lett. 1992, 33, 917.

20. Banwell, M. G.; Jones, M. T.; Reekie, T. A.; Schwartz, B. D.; Tan, S. H.; White, L. V. Org. Biomol. Chem. 2014, 12, 7433.

21. White, L. V.; Banwell, M. G. J. Org. Chem. 2016, 81, 1617.

22. (a) Evarts, J.; Torres, E.; Fuchs, P. L. J. Am. Chem. Soc. 2002, 124, 11093; (b) Houjeiry, T. I.; Poe, S. L.; McQuade, D. T. Org. Lett. 2012, 14, 4394.

23. Still, W. C.; Kahn, M.; Mitra, A. J. Org. Chem. 1978, 43, 2923.

24. Pangborn, A. B.; Giardello, M. A.; Grubbs, R. H.; Rosen, R. K.; Timmers, F. J. Organometallics 1996, 15, 1518.

25. CrysAlis PRO Version 1.171.37.35h (release 09-02-2015 CrysAlis171.NET) (compiled Feb 9 2015,16:26:32) Agilent Technologies: Oxfordshire, UK.

26. SIR92. Altomare, A.; Cascarano, G.; Giacovazzo, C.; Guagliardi, A.; Burla, M. C.; Polidori, G.; Camalli, M. J. Appl. Crystallogr. 1994, 27, 435. 
27. Betteridge, P. W.; Carruthers, J. R.; Cooper, R. I.; Prout, K.; Watkin, D. J. J. Appl. Crystallogr. 2003, 36, 1487. 